\title{
Article \\ Endothelial Nox5 Expression Modulates Glucose Uptake and Lipid Accumulation in Mice Fed a High-Fat Diet and 3T3-L1 Adipocytes Treated with Glucose and Palmitic Acid
}

\author{
Jorge G. García ${ }^{1,2}$, Eduardo Ansorena ${ }^{1,2}$, Fermín I. Milagro ${ }^{2,3,4}\left(\mathbb{D}\right.$, Guillermo Zalba ${ }^{1,2}(\mathbb{D}$ \\ and Carlos de Miguel ${ }^{1,2, *}$ \\ 1 Department of Biochemistry and Genetics, University of Navarra, 31008 Pamplona, Spain; \\ jgarcia.51@alumni.unav.es (J.G.G.); eansorena@unav.es (E.A.); gzalba@unav.es (G.Z.) \\ 2 Navarra Institute for Health Research (IdiSNA), 31008 Pamplona, Spain; fmilagro@unav.es \\ 3 Center for Nutrition Research, Department of Nutrition, Food Science, and Physiology, University of Navarra, \\ 31008 Pamplona, Spain \\ 4 Centro de Investigación Biomédica en Red Fisiopatología de la Obesidad y Nutrición (CIBERobm), Instituto \\ de Salud Carlos III, 28029 Madrid, Spain \\ * Correspondence: cdmigel@unav.es; Tel.: +34-948-425600 (ext. 806462)
}

check for updates

Citation: García, J.G.; Ansorena, E.; Milagro, F.I.; Zalba, G.; de Miguel, C. Endothelial Nox5 Expression

Modulates Glucose Uptake and Lipid Accumulation in Mice Fed a High-Fat Diet and 3T3-L1 Adipocytes Treated with Glucose and Palmitic Acid. Int. J Mol. Sci. 2021, 22, 2729. https:// doi.org/10.3390/ijms22052729

Academic Editor: Masashi Tanaka

Received: 29 January 2021

Accepted: 5 March 2021

Published: 8 March 2021

Publisher's Note: MDPI stays neutral with regard to jurisdictional claims in published maps and institutional affiliations.

Copyright: (c) 2021 by the authors. Licensee MDPI, Basel, Switzerland. This article is an open access article distributed under the terms and conditions of the Creative Commons Attribution (CC BY) license (https:// creativecommons.org/licenses/by/ $4.0 /)$.

\begin{abstract}
Obesity is a global health issue associated with insulin resistance and altered lipid homeostasis. It has been described that reactive oxygen species (ROS) derived from nicotinamide adenine dinucleotide phosphate (NADPH) oxidase (NOX) activity are involved in the development of these pathologies. The present study describes the role of endothelial NOX5 expression over adipose tissue by using two experimental systems: NOX5 conditional knock-in mice fed with a high-fat diet and 3T3-L1 adipocytes cultured with conditioned media of NOX5-expressing endothelial cells previously treated with glucose and palmitic acid. Animals expressing NOX5 presented lower body weight gain and less mesenteric and epididymal adipose mass compared to control mice fed with the same diet. NOX5-expressing mice also showed significantly lower glycaemia and improved insulin-induced glucose uptake. In addition, Glut4 and Caveolin 1 (Cav1) expression were significantly increased in the adipose tissue of these animals. Likewise, 3T3-L1 adipocytes treated with conditioned media from NOX5-expressing endothelial cells, incubated with high glucose and palmitic acid, presented a reduction in lipid accumulation and an increase in glucose uptake. Moreover, a significant increase in the expression of Glut4 and Cav1 was also detected in these cells. Taken together, all these data support that, in response to a highly caloric diet, NOX5 endothelial activity may regulate glucose sensitivity and lipid homeostasis in the adipose tissue.
\end{abstract}

Keywords: obesity; NADPH oxidase 5; lipid homeostasis; glucose uptake; Caveolin 1; Glut4

\section{Introduction}

Obesity is considered a global health issue characterised by an increase in body weight that results in an excessive fat accumulation, disrupting adipose tissue homeostasis [1]. Obesity could lead to metabolic syndrome development, insulin resistance, and type 2 diabetes, which in turn might develop into liver and cardiovascular disorders. [2]. Insulin resistance is defined as a condition produced by the low or inexistent response to high levels of insulin in the organism. In normal conditions, insulin binds to insulin receptors (IR), promoting its activation and its auto-phosphorylation, triggering the translocation of glucose transporter protein (GLUT4) to the cell membrane [3]. Effective insulin signalling in adipocytes may be primarily dependent on the localization of insulin responsive elements (IR and GLUT4) to caveolae, small invaginations of the plasma membrane that are especially abundant in this type of cell. Caveolae, considered signalling platforms, facilitate a rapid activation of IR improving signal transduction [4]. The main structural and functional components of caveolae are caveolins, cholesterol-dependent integral membrane proteins [5]. 
It has been pointed out that caveolin 1 (CAV1) presents a direct functional interaction with the $\beta$-subunit of the IR, enhancing insulin signal transmission [4]. Moreover, CAV1 emerges also as pivotal for the integration of GLUT4 within the plasma membrane [6]. On the other hand, CAV1 has also been involved in adipose tissue homeostasis regulating lipid accumulation $[7,8]$.

One of the mechanisms underlying the relationships among obesity, metabolic syndrome, and type 2 diabetes is the increased production of reactive oxygen species (ROS) $[9,10]$. These increased levels of ROS could act as drivers of redox signalling or even induce oxidative stress when exceeding the balance between their production and degradation [11]. In eukaryotic cells, ROS are commonly generated as products of normal aerobic metabolism and participate in cellular signalling. One of the main producers of ROS in the organism is the family of nicotinamide adenine dinucleotide phosphate (NADPH) oxidases [12] The NADPH oxidase (NOX) family is formed by seven members: homologous NOX1-5 and dual oxidases DUOX1-2. These transmembrane proteins are considered professional oxidases as their primary function is ROS production [13].

Within this family, nicotinamide adenine dinucleotide phosphate (NADPH) oxidase 5 (NOX5) is the most recently discovered member $[14,15]$. This isoform presents a characteristic structural difference consisting in the presence of four EF-hand motifs in the N-terminal part of the protein, which makes NOX5 activity calcium-dependent. Furthermore, it does not need the binding of p22phox subunit for being active [14]. There are six possible splicing variants described, but only the isoforms $1(\alpha)$ and $2(\beta)$ are catalytically active [16]. Some of its biological functions or its involvement in pathophysiological processes remain unclear due to its evolutionary loss in the genome of common laboratory rodent models. In humans, the functional isoforms $\alpha$ and $\beta$ are expressed in the vasculature among other tissues, with $\beta$ isoform being the predominant in the endothelial cells of the intima $[16,17]$.

NOX enzymes have been implicated in the pathology of metabolic disorders [18]. Nutrients such as glucose and fatty acids play a regulatory role in the expression and activity of some NOX family members, and some of these proteins contribute to obesity-associated insulin resistance [19]. Additionally, ROS plays a role in adipocyte differentiation [20,21]. Interestingly, some studies have proved that NOX4-derived superoxide enhances glucose uptake as well as adipocyte differentiation [21,22]. A direct interaction between caveolae and NOX enzymes has also been shown. A recent study has revealed that NOX5 is present in caveolae from vascular smooth muscle cells [23]. In this regard, it has been described that CAV1 can bind to NOX5 promoting a decrease of its activity [24]. There is a close relationship between metabolic tissues and the vasculature, and an increasing amount of evidence illustrates that there are intense cross-signalling between them [25]. Understanding the physiological and pathophysiological roles of vascular NOX5 in the development and progression of metabolic diseases is desirable since obesity and type 2 diabetes entail a greater risk of cardiovascular mortality [18]. In this context, the aim of this study was to determine whether endothelial NOX5 expression in mice fed with a high-fat diet (HFD) could have an effect in insulin signalling and the homeostasis of adipose tissue. For that purpose, a novel humanised NOX5 conditional knock-in mice, developed by our group [26], was used. The principal finding of this work shows that endothelial NOX5 expression modulated glucose uptake and lipid accumulation in the adipose tissue of mice fed with a high-fat diet, accompanied with a significant increase in the expression of GLUT4 and CAV1. This effect was confirmed in cultured 3T3-L1 adipocytes incubated with conditioned media released from NOX5-expressing endothelial cells exposed to high levels of glucose and palmitic acid.

\section{Results}

2.1. Endothelial NOX5 Expression Reduced Body Weight Gain and Adipose Tissue Weight in Mice Fed a High-Fat Diet

Control CRE recombinase (CRE) or endothelial NOX5-expressing mice were fed either with a control or a high-fat diet (HFD) for 10 weeks. Body weight gain was determined each week and organ tissue weights were measured at the time of sacrifice. Body weight 
gain experienced a continuous increase over the 10 weeks of treatment in both groups, becoming significantly higher after the second week of treatment in those animals fed with the HFD. More importantly, endothelial NOX5-expressing mice fed with the HFD presented lower body weight gain than their control CRE counterparts. This decrease, caused by the difference in genotype, became significant since the fifth week of diet (Figure 1A). Accordingly, weights of mesenteric and epididymal fat tissues from mice fed with the HFD were significantly increased after 10 weeks of treatment compared to mice fed a control diet. Noteworthy, endothelial NOX5 expression tended to reduce the weight of mesenteric and epididymal fat in mice fed with HFD compared to their control CRE counterparts. This decrease was significant for epididymal fat (Figure 1B,C).

A

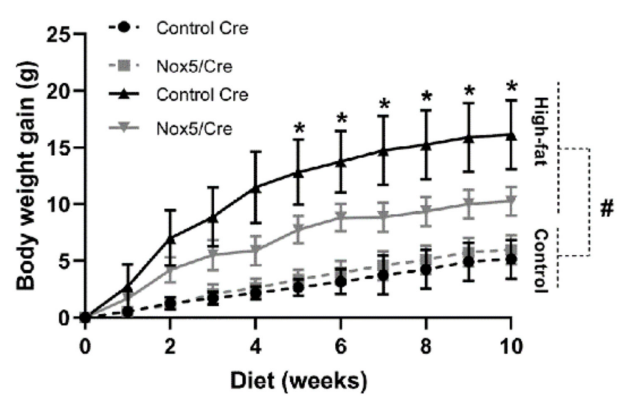

B

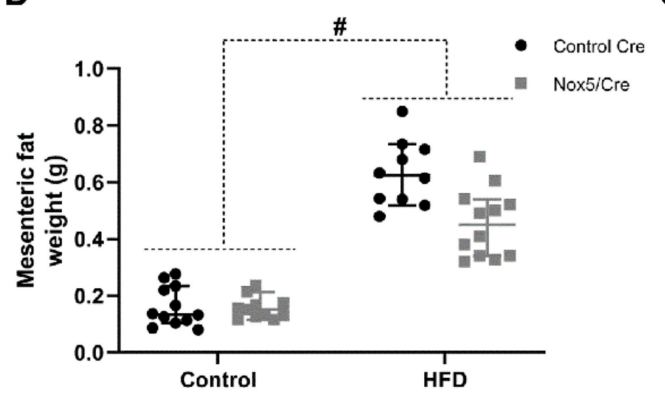

C

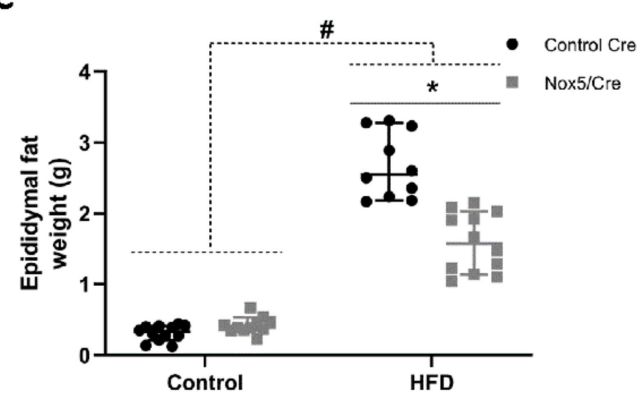

Figure 1. Endothelial NOX5expression reduced total body weight gain and the amounts of mesenteric and epididymal adipose tissues in mice fed a HFD for 10 weeks. (A) Body weight gain. (B) Mesenteric fat weight. (C) Epididymal fat weight. Control diet: control Cre $(n=12)$, Nox5/Cre $(n=11)$; high-fat diet: control Cre $(n=10)$, Nox5/Cre $(n=12)$. Values are expressed as median with confidence interval. $\# p<0.05$ : diet differences (dotted lines); ${ }^{*} p<0.05$ : genotype differences (solid lines). Statistical tests used: Aligned Rank ANOVA.

\subsection{Endothelial NOX5 Expression in Mice Fed a High-Fat Diet Enhanced Glucose Sensitivity}

An intraperitoneal glucose tolerance test was performed measuring blood glucose levels in mice fed either with a control or a HFD for 9 weeks, 1 week before sacrifice. As expected, diet effect provoked that mice fed with the HFD presented higher blood glucose levels throughout the analysed period, compared to mice fed a control diet (Figure 2A,B). In mice fed a control diet, no differences were patent due to genotype. Interestingly, within the group fed with the HFD, mice expressing endothelial NOX5 presented lower blood glucose levels. This difference became significant 100 and $160 \mathrm{~min}$ after the intraperitoneal administration of glucose, indicating that the difference in genotype modulated glucose uptake. Thus, NOX5 expression seemed to improve glucose sensitivity in these conditions (Figure 2B). 
A

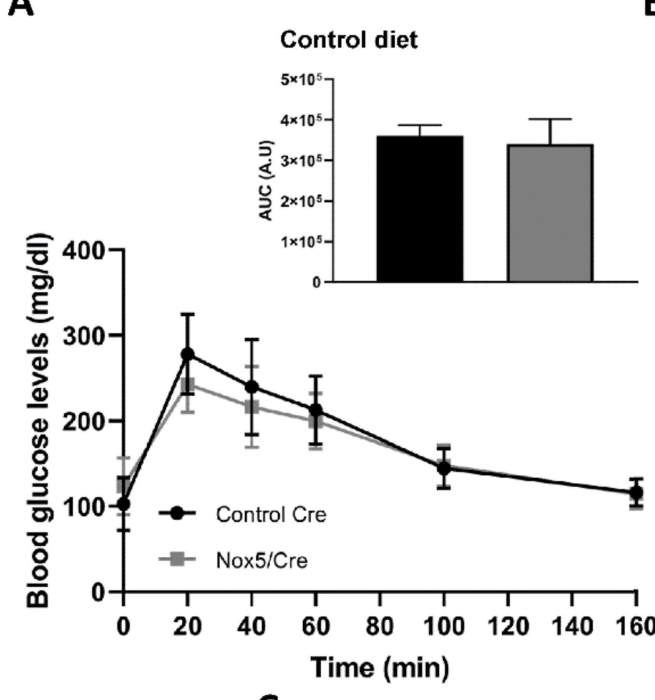

B

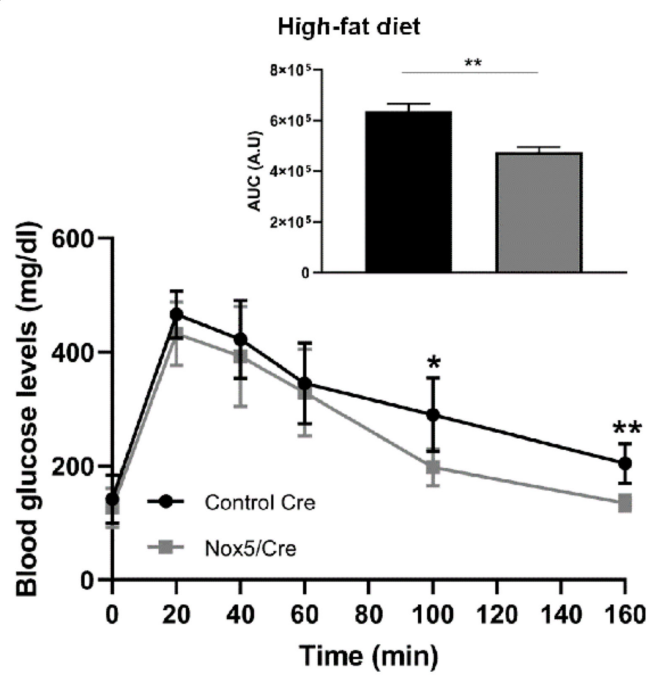

C

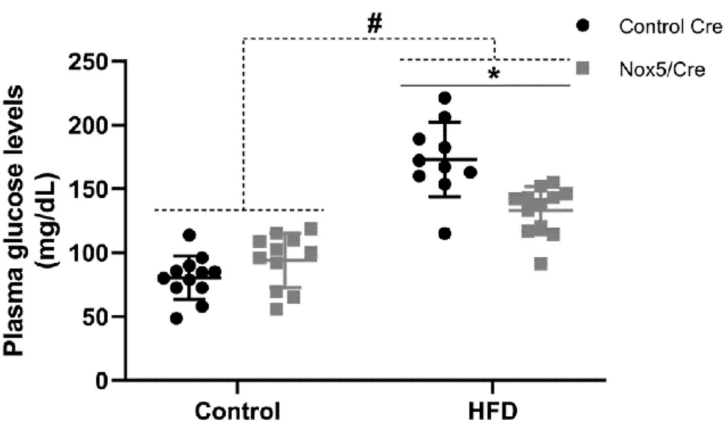

Figure 2. Endothelial NOX5 expression improved glucose uptake and reduced glycaemia in mice fed a HFD. (A) Intraperitoneal glucose tolerance test (IPGTT) performed in animals fed a control diet for 9 weeks. (B) IPGTT performed in animals fed a HFD for 9 weeks. (C) Plasma glucose levels after 10 weeks. Control diet: control Cre $(n=12)$, Nox5/Cre $(n=11)$; high-fat diet: control Cre $(n=10)$, Nox $5 / C r e(n=12)$. Values are expressed as mean \pm standard error of the mean (SEM). $\# p<0.05$ : diet differences (dotted lines); ${ }^{*} p<0.05,{ }^{* *} p<0.01$ : genotype differences (solid lines). Statistical tests used: $t$-test for $(\mathbf{A}, \mathbf{B})$, and area under the curve (AUC); two-way ANOVA for (C). A.U: arbitrary units.

Biochemical analysis revealed that plasma glucose levels were also significantly increased in mice fed the HFD for 10 weeks (Figure 2C). Differences in genotype provoked that among animals fed with the HFD, mice expressing endothelial NOX5 experienced a significant reduction in glycaemia (Figure 2C). Other biochemical parameters determined from plasma samples showed that mice expressing endothelial NOX5 and fed with the HFD tended to present lower levels of cholesterol, high-density lipoprotein (HDL), triglycerides (TAG), and alanine transaminase (ALT) than control CRE mice (Table S1). Additionally, ROS production was indirectly measured by detecting albumin nitrotyrosine levels in mesenteric fat (Figure S1). Nitrotyrosine levels of this protein were significantly increased in mice fed the HFD for 10 weeks. Moreover, differences in genotype caused that among animals fed the HFD, mice expressing endothelial NOX5 experienced a significant increase in albumin nitrotyrosine levels, reflecting an increase in ROS production.

\subsection{Endothelial Expression of NOX5 in Mice Fed a High-Fat Diet Increased the Expression of Genes Related to Glucose Uptake Pathway in Adipose Tissue}

The expression of different genes associated with glucose sensitivity was evaluated in the adipose tissue of animals subjected to control or to a HFD for 10 weeks. Glut4 expression was evaluated in samples obtained from mesenteric and epididymal fat. The HFD group showed that mRNA levels of Glut4 were significantly higher in both tissues. In ad- 
dition, endothelial NOX5 expression in mice fed the HFD induced a significant increase of Glut4 mRNA levels in both tissues, showing relevant differences due to genotype (Figure 3A,B). This NOX5 genotype effect on Glut4 expression was confirmed at protein levels in epididymal fat, where it became clear even with the control diet (Figure 3D). On the other hand, in mesenteric fat, only those animals fed a HFD and expressing endothelial NOX5 showed a tendency to increase GLUT4 protein levels (Figure 3C).

A

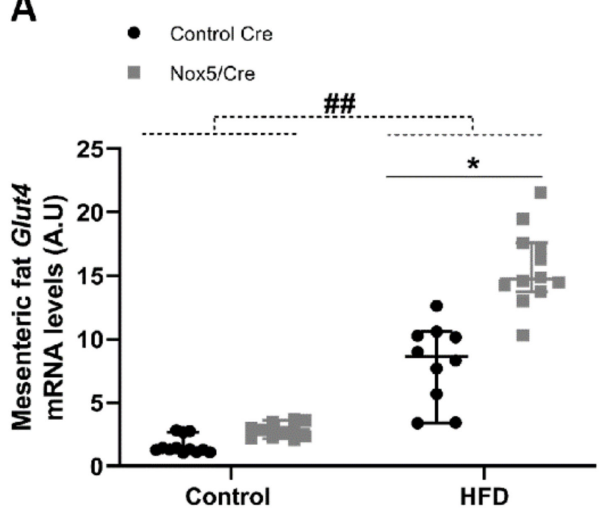

C
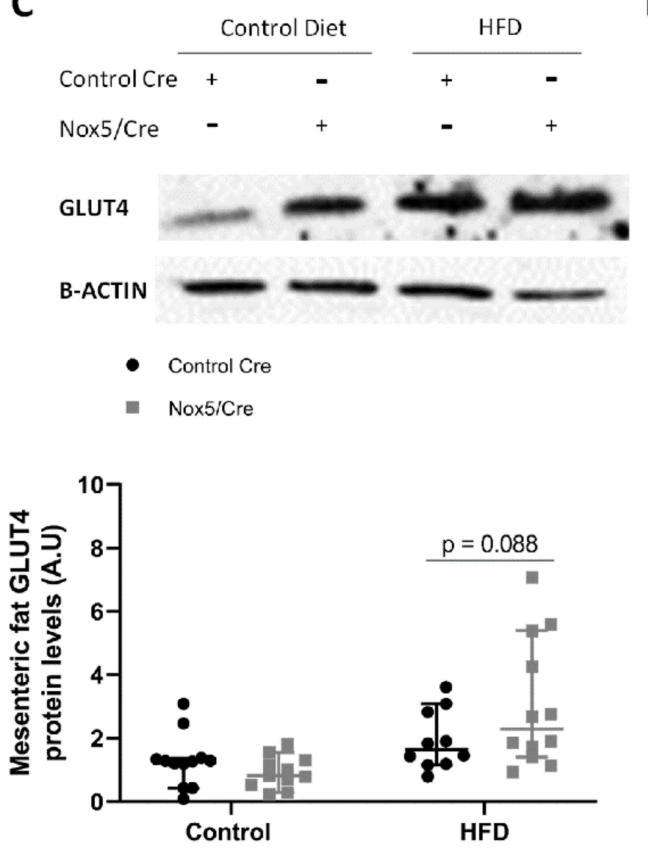

B

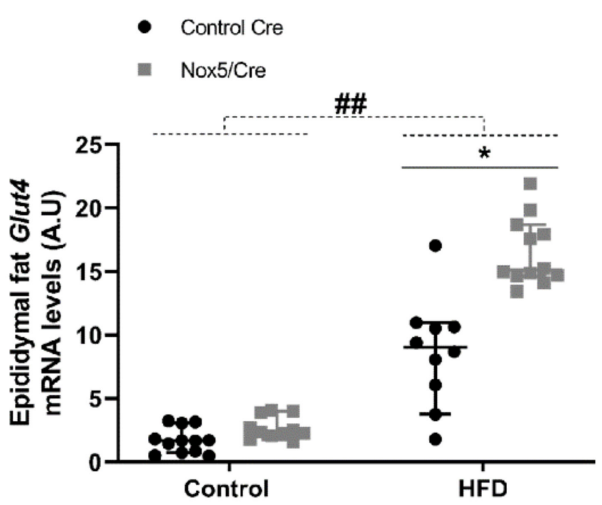

D

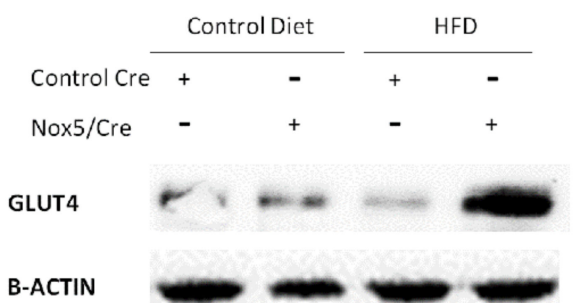

- Control Cre

- Nox5/Cre

$\#$

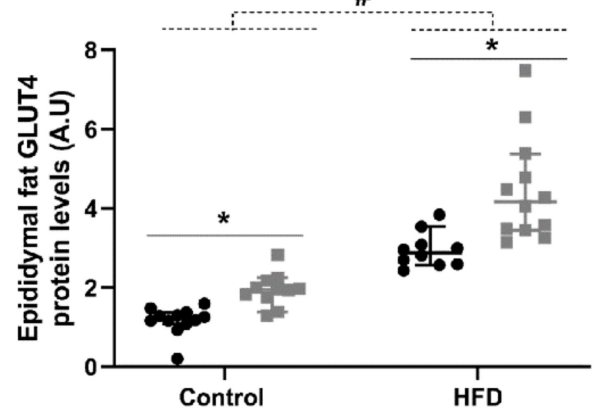

Figure 3. Endothelial NOX5 expression increased Glut4 levels in mesenteric and epididymal fat in mice fed a HFD for 10 weeks. (A,B) Glut4 mRNA levels in (A) mesenteric fat and (B) epididymal fat. (C,D) Representative Western blot and protein levels of GLUT4 in total lysates of (C) mesenteric fat and (D) epididymal fat. Control diet: control Cre $(n=12)$, Nox5/Cre $(n=11)$; high-fat diet: control Cre $(n=10)$, Nox5/Cre $(n=12)$. Values are expressed as median with confidence interval. mRNA levels are relative to Gapdh. Protein levels are relative to B-ACTIN. $\# p<0.05$, \#\# $p<0.01$ : diet differences (dotted lines); ${ }^{*} p<0.05$ : genotype differences (solid lines). Statistical test used: Aligned Rank ANOVA.

In the case of Ir-B, the HFD feeding induced increased levels of mRNA in both mesenteric and epididymal fat, whereas NOX5 endothelial expression did not elicited appreciable differences due to the genotype in either of the diet conditions (Figure 4A,B). At protein levels, NOX5 endothelial expression only induced a significant increase of IR-B in epididymal fat (Figure 4C,D). 
A

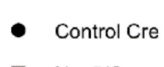

- Nox $5 / \mathrm{Cr}$

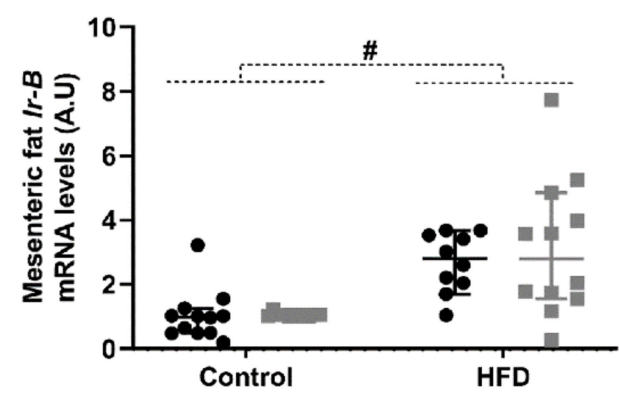

C

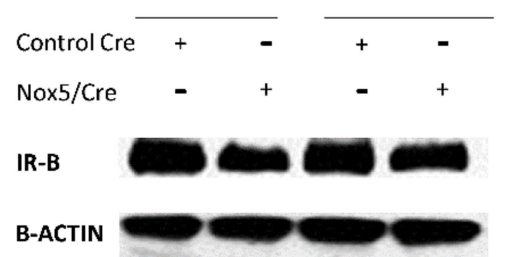

- Control Cre

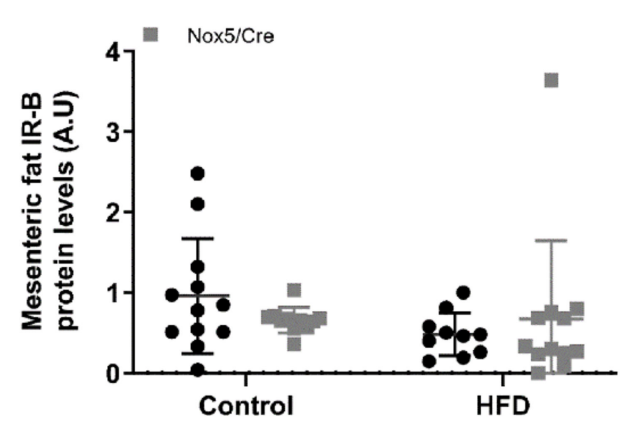

B

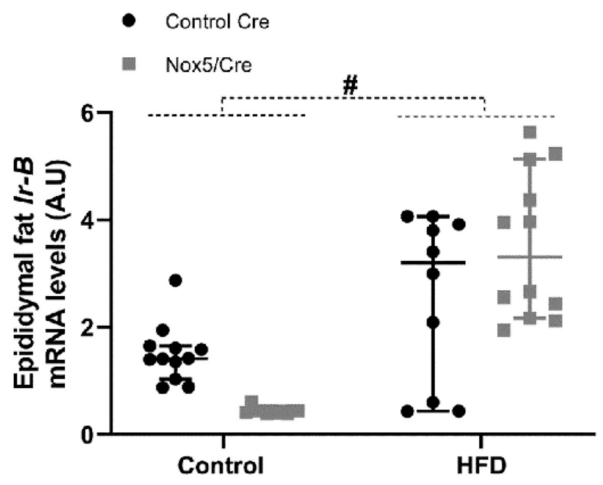

D
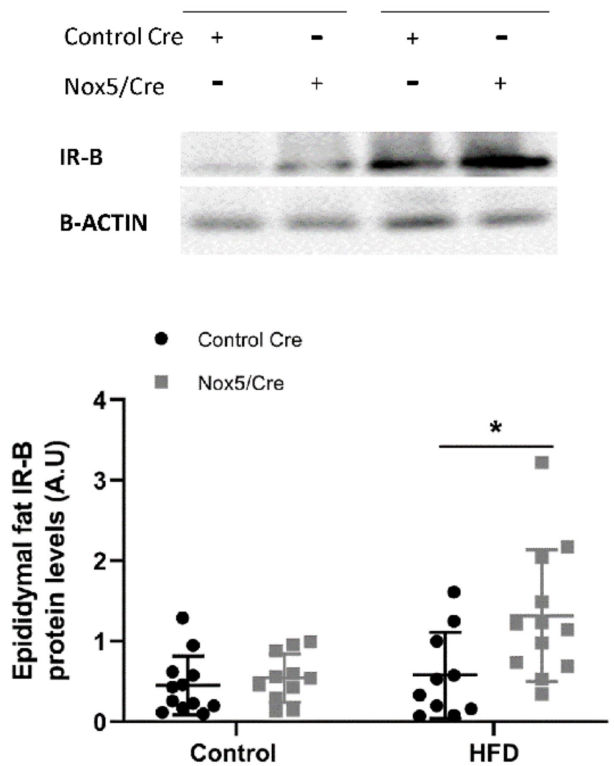

Figure 4. Endothelial NOX5 expression increased Ir-B expression in epididymal but not in mesenteric fat in mice fed a HFD for 10 weeks. (A,B) Ir-B mRNA levels in (A) mesenteric fat and (B) epididymal fat. (C,D) Representative Western blot and protein levels of IR-B in total lysates of (C) mesenteric fat and (D) epididymal fat. Control diet: control Cre $(n=12)$, Nox5/Cre $(n=11)$; high-fat diet: control Cre $(n=10)$, Nox5/Cre $(n=12)$. Values are expressed as median with confidence interval. mRNA levels are relative to Gapdh. Protein levels are relative to B-ACTIN. \# $p<0.05$ : diet differences (dotted lines); ${ }^{*} p<0.05$ : genotype differences (solid lines). Statistical test used: Aligned Rank ANOVA.

For Cav1, administration of a HFD induced a significant increase in mRNA levels in both adipose tissues (Figure 5A,B). Additionally, endothelial NOX5 expression had a remarkable effect in Cav1 expression also in both adipose tissues, showing a significant increase, not only of mRNA, but also of protein levels (Figure 5A-D). IR and Cav1 were also analysed in liver samples, where endothelial NOX5 expression in mice fed with the HFD showed a tendency to increase CAV1 protein levels (Figure S2). 
A

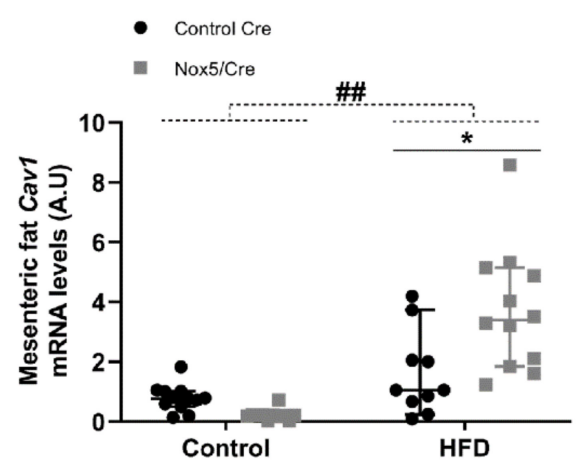

C

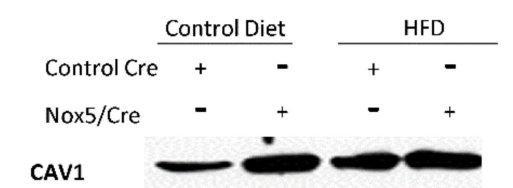

B-ACTIN

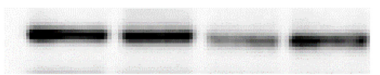

- Control Cre

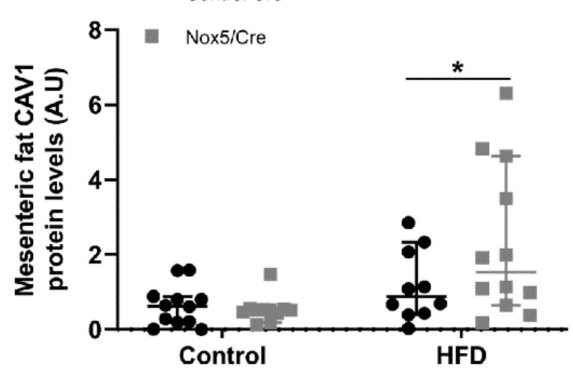

B

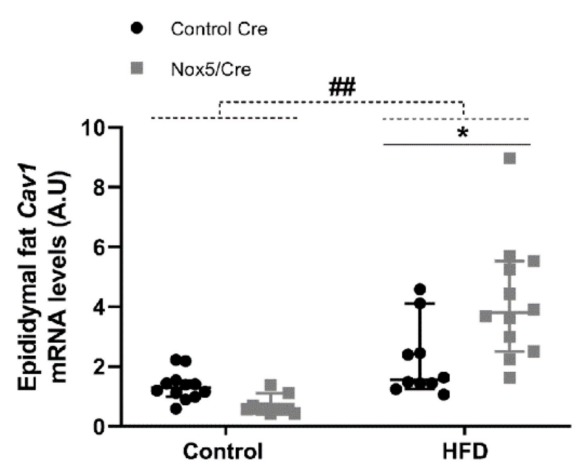

D

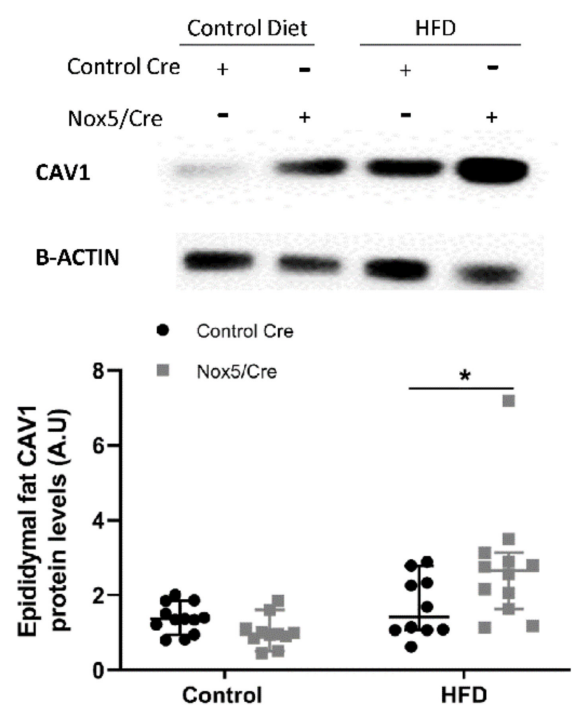

Figure 5. Endothelial NOX5 expression increased Cav1 expression in mesenteric and epididymal fat in mice fed a HFD for 10 weeks. (A,B) Cav1 mRNA levels in (A) mesenteric fat and (B) epididymal fat. (C,D) Representative Western blot and protein levels of CAV1 in total lysates of (C) mesenteric fat and (D) epididymal fat. Control diet: control Cre $(n=12)$, Nox5/Cre $(n=11)$; high-fat diet: control Cre $(n=10)$, Nox5/Cre $(n=12)$. Values are expressed as median with confidence interval. mRNA levels are relative to Gapdh. Protein levels are relative to B-ACTIN. \#\# $p<0.01$ : diet differences (dotted lines); ${ }^{*}<0.05$ : genotype differences (solid lines). Statistical test used: Aligned Rank ANOVA.

Taking all this data into account, we could infer that endothelial expression of NOX5 in mice modulates the expression of some relevant genes related to glucose uptake in the adipose tissue of mice fed with a HFD.

2.4. T3 Adipocytes Cultured with Conditioned Media from Endothelial NOX5-Expressing Cells Showed Reduced Lipid Accumulation and Increased Glucose Uptake Together with Enhanced Expression of Genes Related to Glucose Uptake Pathway

An in vitro cell-based model system employing 3T3-L1 adipocytes and NOX5-transfected bEnd.3 endothelial cells was developed in order to confirm the results obtained in the in vivo model with the HFD-fed mice. For that purpose, 3T3-L1 adipocytes were treated for $24 \mathrm{~h}$ with conditioned media from NOX5-expressing bEnd.3 endothelial cells, which had been previously incubated with $30 \mathrm{mM}$ glucose and $300 \mu \mathrm{M}$ palmitic acid for $24 \mathrm{~h}$ (Glu + PA conditioned media). Addition of glucose and palmitic acid was performed $24 \mathrm{~h}$ after the transfection of the endothelial cells with NOX5 expression vector and was intended to simulate the conditions found in animals fed with a HFD, having high concentration of glucose and fatty acids. NOX5 expression and ROS levels derived from its activation were determined in bEnd.3 cells (Figure S3). 
In order to measure the accumulation of neutral triglycerides and lipids in the in vitro system, 3T3-L1 adipocytes were stained with Oil Red after treatment with conditioned media obtained from the endothelial cells. As it can be inferred from Figure 6A,B, only Glu + PA conditioned media derived from NOX5-expressing cells induced a significant reduction of lipid accumulation.

In addition, after $100 \mathrm{nM}$ insulin stimulation, glucose uptake of 3T3-L1 adipocytes treated under the different experimental conditions was analysed. In this case, 3T3-L1 adipocytes treated with conditioned media from NOX5-expressing cells presented a significant increase in glucose uptake independently of the previous incubation of these cells with Glu + PA (Figure 6C).

A
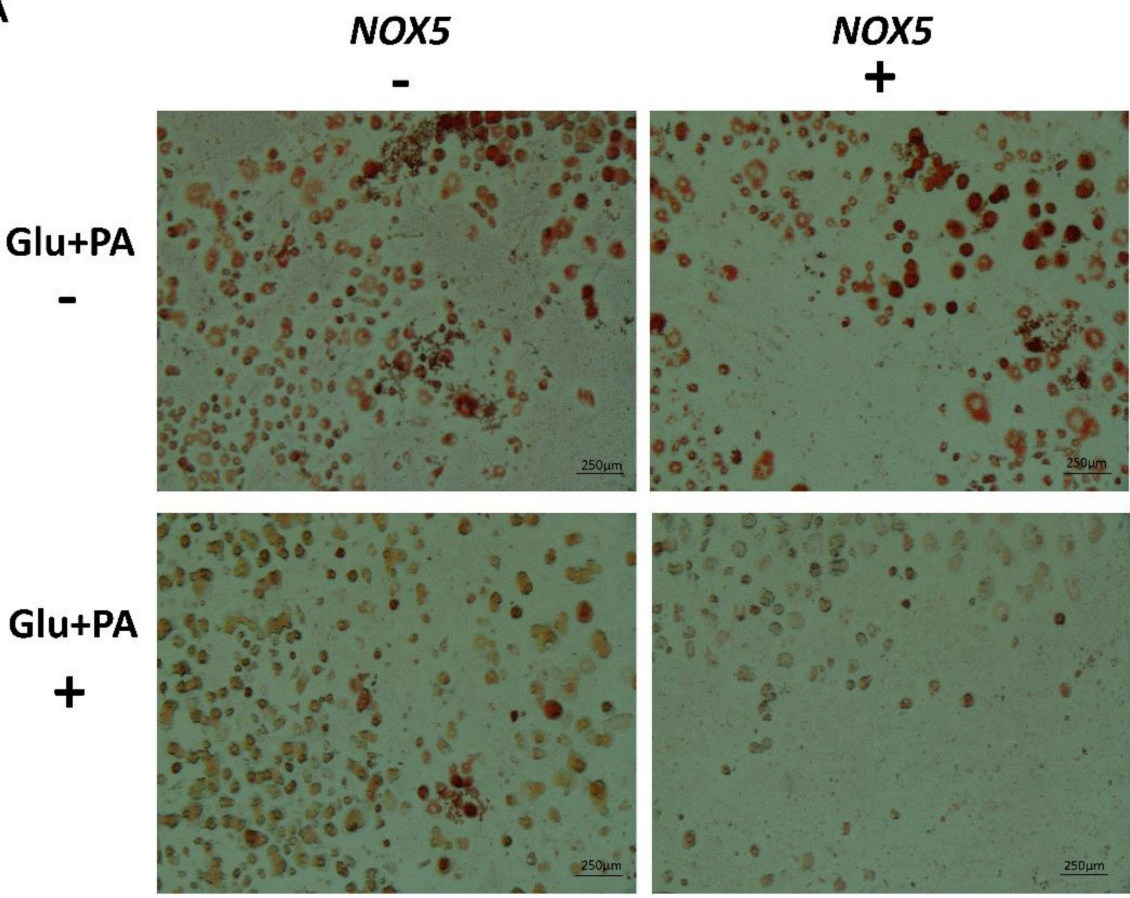

B
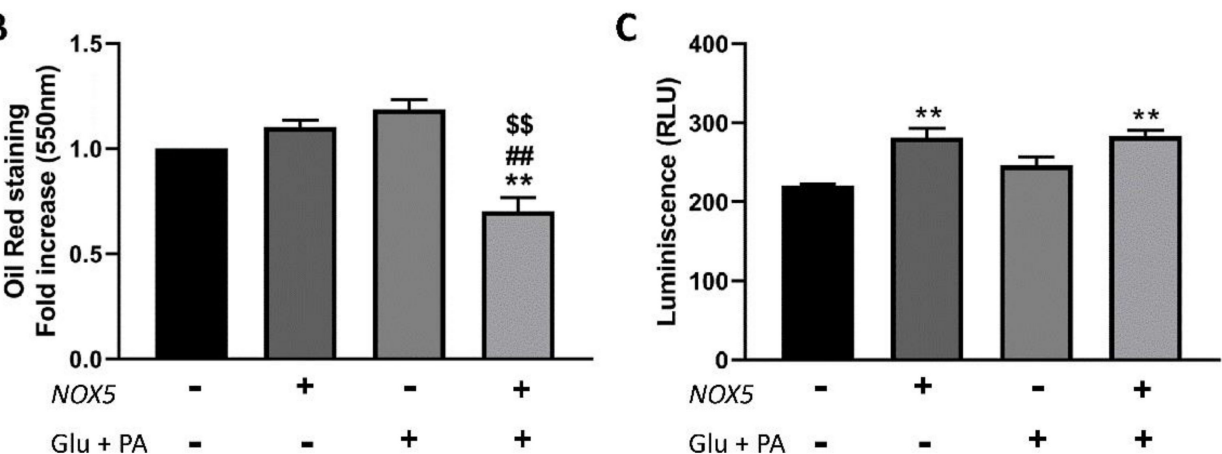

Figure 6. 3T3-L1 adipocytes showed a reduction of lipid accumulation when incubated for $24 \mathrm{~h}$ with glucose (Glu) + palmitic acid (PA) conditioned media from NOX5-expressing endothelial bEnd. 3 cells and an increase of glucose uptake even without the previous incubation with Glu + PA. (A) Representative images of Oil Red staining $(n=3)$. (B) Oil Red quantification at $550 \mathrm{~nm}(n=3)$. (C) Glucose uptake quantification of 3T3-L1 adipocytes through luminescence after stimulation with $100 \mathrm{nM}$ insulin. Fold increase is relative to the control group $(\operatorname{Nox}(-) / \mathrm{Glu}+\mathrm{PA}(-))$. Values are expressed as mean $\pm \mathrm{SEM}$. ${ }^{* *} p<0.01$ : differences relative to $\operatorname{Nox}(-) / \mathrm{Glu}+\mathrm{PA}(-)$; \#\# $p<0.01$ : differences relative to $\operatorname{Nox}(+) / G l u+P A(-) ; \$ \$<0.01$ : differences relative to Nox $(-) / \mathrm{Glu}+\mathrm{PA}(+)$. Statistical test used: ANOVA. 
Finally, the expression of the relevant genes associated with glucose uptake in adipocytes (Glut4, Ir-B, and Cav1) (Figure 7) was also analysed. In agreement with the previous in vivo mice model results, 3T3-L1 adipocytes treated with Glu + PA conditioned media derived from NOX5-expressing endothelial cells experienced a significant increase in mRNA and protein levels of Glut4 (Figure 7A,B) and Cav1 (Figure 7E,F).

A

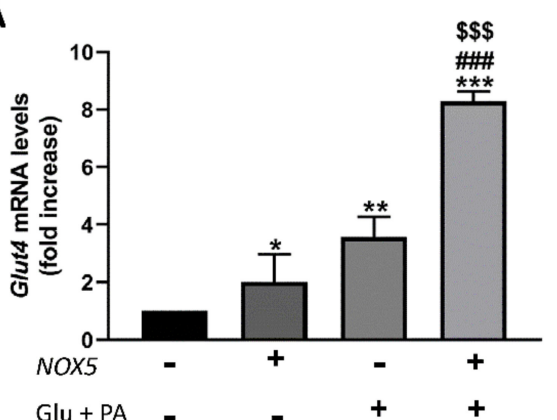

C

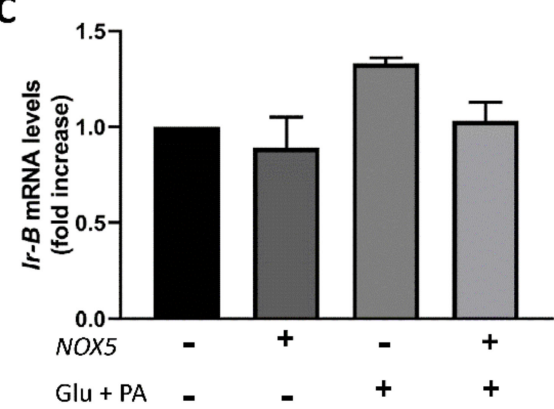

$\mathbf{E}$

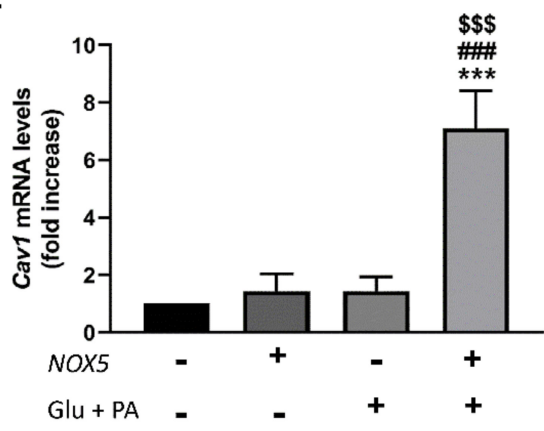

G

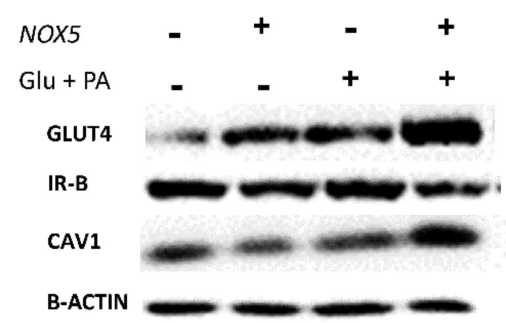

B
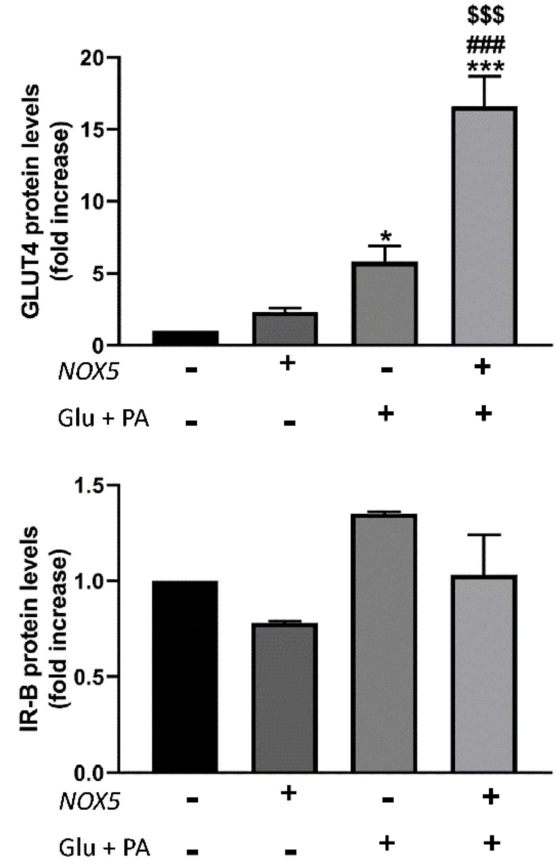

$\mathbf{F}$

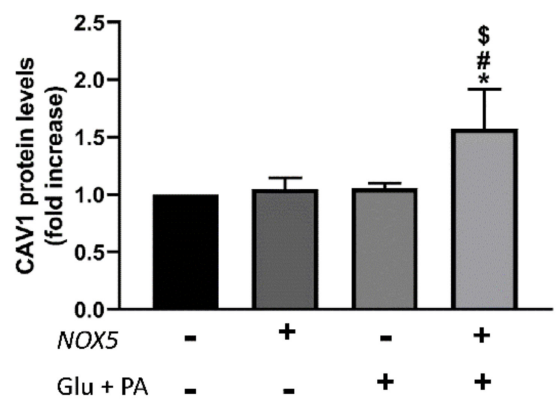

Figure 7. Glut4 and Cav-1 expression was increased in 3T3-L1 adipocytes when incubated for $24 \mathrm{~h}$ with Glu + PA conditioned media from NOX5-expressing endothelial bEnd.3 cells. (A,C,E) Glut4, Ir-B, and Cav1 mRNA levels of 3T3-L1 adipocytes $(n=3)$. (B,D,F) GLUT4, IR-B, and CAV1 protein levels of 3T3-L1 adipocytes $(n=3)$. (G) Representative images of Western blot for GLUT4, IR-B, and CAV1. mRNA levels are relative to GAPDH; protein levels are relative to $\beta$-actin. Fold increase is relative to the control group (Nox $(-) / \mathrm{Glu}+\mathrm{PA}(-))$. Values are expressed as mean $\pm \mathrm{SEM} ;{ }^{*} p<0.05,{ }^{* *} p<0.01$, ${ }^{* * *} p<0.001$ : differences relative to $\operatorname{Nox}(-) / \mathrm{Glu}+\mathrm{PA}(-)$; \# $p<0.05$, \#\#\# $p<0.001$ : differences relative to $\operatorname{Nox}(+) / \mathrm{Glu}+\mathrm{PA}(-) ; \$ p<0.05, \$ \$ p<0.001$ : differences relative to $\operatorname{Nox}(-) / \mathrm{Glu}+\mathrm{PA}(+)$. Statistical test used: ANOVA. 
Taken together, these observations indicate that the exposure of endothelial cells expressing NOX5 to high concentrations of glucose and fatty acids (palmitic) prompt the production of molecular signals that cause a reduction in lipid accumulation and an increase in insulin-induced glucose uptake in the neighbouring adipocytes.

\section{Discussion}

Obesity is recognized as one of the leading health problems affecting western countries. One of the circumstances generally associated with obesity is oxidative stress, which is the result of an imbalance between ROS production and degradation [27]. NADPH oxidases (NOXs) are one of the main contributors to ROS homeostasis. Several studies have reported the implication of different NOXs, especially NOX2 and NOX4, in the development of insulin resistance associated with obesity $[11,28,29]$. However, little is known about the role of NOX5 due to its evolutionary loss in the rodent genome. A recent study shows that pancreatic NOX5 expression in presence of a HFD impairs insulin action [30]. The expression of NOX5 has been frequently associated as a response to an insult or a stress [31] and has been commonly related to a deterioration of the pathology [32]. On the other hand, other studies suggest that NOX5 expression could improve some conditions such as cardiac remodelling or monocytic differentiation into dendritic cells $[26,33,34]$.

In our study, endothelial NOX5 expression seemed to reduce body weight gain and adipose tissue enlargement in mice fed a HFD (Figure 1). Biochemical parameters related to obesity (cholesterol, TAG, glucose) were also reduced in these animals (Table S1, Figure 2). Furthermore, in vitro studies show that 3T3-L1 adipocytes cultured with Glu + PA conditioned media from NOX5-expressing bEnd.3 endothelial cells presented lower lipid accumulation (Figure 6A,B). In accordance with our results, a knockout mice model for NOX4 seemed to facilitate weight gain and obesity development [35]. Although we cannot conclude whether our results are related to molecular signals derived from NOX5 activity, other studies have shown a similar relationship between ROS and lipid homeostasis. ROS derived from mitochondrial activity from the hypothalamus have been reported to control lipid sensing and satiety $[36,37]$. As control Cre and NOX5/Cre-expressing mice fed with control diet presented no differences, our results suggest that in the presence of a high energy supply, such as feeding with a HFD, the endothelial NOX5 expression might help in body weight control.

In this work, we also found that mice expressing endothelial NOX5, when challenged with a HFD, showed a better response to the IPGTT (Figure 2A,B), presenting a significantly lower blood glucose level $100 \mathrm{~min}$ after glucose injection, which reflected an improved glucose uptake response. The in vitro model of 3T3-L1 adipocytes treated with Glu + PA conditioned media from NOX5-expressing bEnd.3 endothelial cells confirmed this result (Figure 6C). These cells showed an increased insulin-stimulated glucose uptake compared to adipocytes treated with Glu + PA conditioned media from non-transfected bEnd.3 endothelial cells. Interestingly, in this case, 3T3-L1 adipocytes treated with conditioned media from NOX5-expressing bEnd.3 endothelial cells, but without previous incubation with Glu + PA, also showed increased insulin stimulated glucose uptake. It seems that in this isolated cell model, NOX5 expression in the endothelial cell was sufficient to ameliorate insulin response in the adipocytes. These results suggest that ROS production in the endothelial cells, derived from NOX5 expression, induces the generation of molecular signals that when reaching the neighbouring adipocytes are able to elicit a response that improves insulinstimulated glucose uptake in these cells. In vivo, this effect seems to be appreciable only in HFD-fed animals, perhaps as an initial adaptive defence mechanism against the nutrient excess. HFD would increase calcium entrance into the cells [38], allowing NOX5 activation. NOX5-derived ROS could regulate glucose homeostasis, eliciting the production of signals in a less direct way than improved insulin signalling by NOX4-derived superoxide [22].

On the other hand, it is generally accepted that a prolonged situation of over-excess feeding comes down to the development of insulin resistance and type 2 diabetes [39]. Even though it has been reported that oxidative stress plays an important role in this 
process [20], some studies have proven that basal levels of ROS are essential for insulin sensitivity [40]. For example, a Gpx1 (glutathione peroxidase 1) knockout mice model produced an increase in ROS levels that resulted in an improved insulin sensitivity through Pi3k/Akt signalling. In another model, mice with an accelerated skeletal muscle senescence showed an increase of mitochondrial ROS levels that resulted in a better sensitivity towards insulin [41,42]. To further analyse the improvement in insulin response as a consequence of NOX5 expression, we measured the expression levels of two initial intermediaries in insulin signal transmission, namely, $I r-B$ and Cav1, as well as the final effector, glucose transporter Glut4. In accordance with previous results [43], mice fed a HFD showed elevated expression of the three intermediaries in mesenteric and epididymal white adipose tissue. Notably, when these mice expressed endothelial NOX5, there was a significant induction mainly in the expression of Cav1 and Glut4 (Figures 3-5). Again, the in vitro model confirmed these results, and when 3T3-L1 adipocytes were treated with Glu + PA conditioned media coming from NOX5-expressing bEnd.3 endothelial cells, the expression of Cav1 and Glut4 was found to be significantly augmented (Figure 7).

Insulin-stimulated glucose uptake is accomplished through triggered translocation of the glucose transporter GLUT4 from intracellular vesicular reservoirs to the plasma membrane [44]. Membrane caveolae, where CAV1, IR-B, and GLUT4 colocalize, have been shown to be essential in this process. CAV1 activation by the IR upon insulin binding facilitates insulin signal transduction that leads to the translocation of GLUT4 to the plasma membrane [45-47]. Therefore, our results advocate that NOX5 expression in the endothelium helps to elicit an initial response against the excess of nutrients that contains a hyper-caloric diet such as the high-fat content diet used to feed the animals in this study. One effect of this early response is the enhanced insulin sensitivity of the white adipose tissue, which shows increased glucose uptake. The higher levels of Cav1 and Glut4 measured may form part of the necessary adjustments. Moreover, CAV1 is also involved with lipid accumulation. Studies performed with Cav1 knockout mice have shown that a reduction of Cav1 expression in the organism reflects in a higher hypertriglyceridemia $[48,49]$. As a result, the increase in Cav1 expression would explain the lower weight gain and lower weights of adipose tissue from mice expressing NOX5 and fed with a HFD.

Finally, the fact that NOXs have been reported to be found within caveolae in endothelium [23,24], as well as in adipose tissue [19], and that they can interact with CAV1, raises the possibility of a cross-regulation, something that deserves further investigation. In regard to this, it is interesting the finding that ROS may enhance CAV1 transcription in NIH-3T3-L1 fibroblasts [50].

In summary, we found that the expression of NOX5 in the endothelium under obesity conditions is able to induce an upregulation of important insulin signalling intermediaries, such as $I r-B, C a v 1$, and Glut4 in the neighbouring adipose cells. This is associated with an improved insulin-response increasing glucose uptake by the adipocytes and also in a reduced lipid accumulation (Figure 8). These results suggest that endothelial NOX5 may have a role in modulating a protective adipose tissue adaptation to the excess of nutrients caused by a high-fat diet in order to avoid, or at least delay, lipid accumulation and insulin resistance development. 


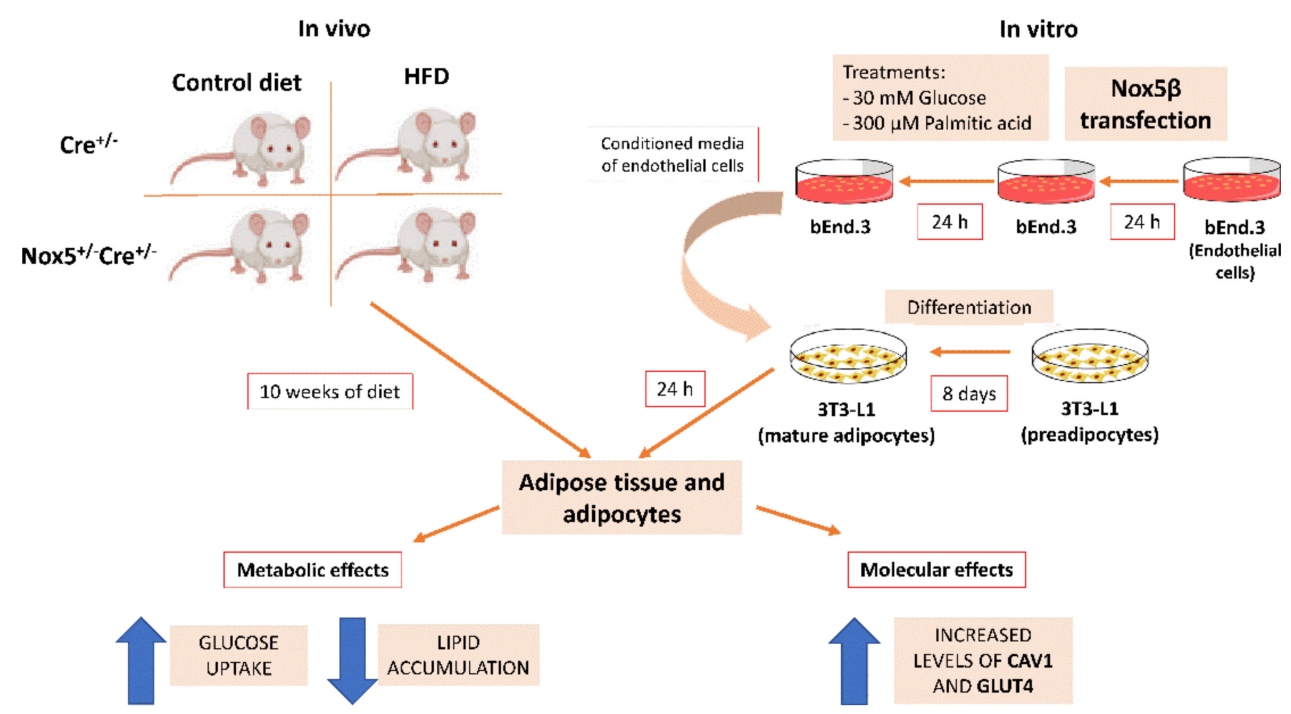

Figure 8. Graphical scheme of the experimental design and principal findings.

\section{Materials and Methods}

\subsection{Animals}

A novel humanised knock-in mice for the endothelial expression of NOX5-B were employed in this study (Nox5+/-Cre+ /-) [26]. Endothelial-specific CRE recombinaseexpressing mice (CRE+/-) were used as control group (control CRE). Seven-week-old male mice were fed ad libitum with high-fat diet (HFD) or control diet for 10 weeks. HFD was a commercial obesogenic diet consisting of $60 \%$ calories as fat and $20 \%$ for both protein and carbohydrates (OpenSource Diet Product Data-D12492, Research Diets, New Brunswick, NJ, USA). At the time of sacrifice, tissue samples were rapidly extracted, weighted, and stored at $-80^{\circ} \mathrm{C}$ until they were processed. All in vivo experiments were performed in accordance with the European Communities Council Directives guidelines for the care and use of laboratory animals (2016/63/EU) and were approved by the University of Navarra Animal Research Review Committee (Protocol 106-17). Mice were randomly distributed in different cages with a maximum of 6 animals per cage.

\subsection{Intraperitoneal Glucose Tolerance Test (IPGTT)}

IPGTT was carried out at the ninth week of treatment, 1 week before sacrifice. First, mice were weighted and a 30\% w/v glucose (Sigma Aldrich, St. Louis, MO, USA) solution was intraperitoneally administered at a concentration of $2 \mathrm{~g} / \mathrm{kg}$. Venous blood samples were obtained from the tail and glucose levels were determined using a glucometer (AccuCheck Aviva, Roche Diagnostics, Rotkreuz, Switzerland). Glucose measurements were recorded at $0,20,40,60,100$, and $160 \mathrm{~min}$ after the administration.

\subsection{Plasma Biochemistry Parameters}

Blood was directly extracted from the heart immediately after mice were sacrificed. Blood samples were mixed with $0.1 \mathrm{M}$ sodium citrate (Merck, Darmstadt, Germany) and maintained in ice for $15 \mathrm{~min}$. Samples were then centrifuged $\left(2000 \times \mathrm{g}\right.$ at $4{ }^{\circ} \mathrm{C}$ for $\left.15 \mathrm{~min}\right)$ in order to obtain plasma that was stored at $-80^{\circ} \mathrm{C}$.

Biochemistry parameters were determined from plasma samples in a Pentra C200 autoanalyzer (Horiba, Kyoto, Japan) with specific kits for each parameter.

\subsection{Materials}

Dulbecco's modified Eagle's medium (DMEM), foetal bovine serum (FBS), $0.25 \%$ $w / v$ trypsin-EDTA, $1 \% w / v$ penicillin-streptomycin solution, phosphate-buffered saline (PBS), Opti-MEM, and Lipofectamine 3000 were purchased from Gibco (Thermo Fisher Scientific, Inc., Waltham, MA, USA). Insulin, water-soluble dexamethasone, 3-isobutyl- 
1-methylxanthine (IBMX), palmitic acid (PA), and glucose (Glu) were purchased from Sigma Aldrich (St. Louis, MO, USA). General chemicals reagents were purchased from Sigma Aldrich unless otherwise specified. Cell culture plastics were obtained from Corning (Thermo Fisher Scientific, Inc., Waltham, MA, USA).

\subsection{Cell Culture}

bEnd.3 (CRL-2299) and 3T3-L1 (CL-173) were obtained from ATCC (American Type Culture Collection, Manassas, VA, USA). Cells were grown in complete medium based on DMEM supplemented with $10 \%$ FBS and $0.1 \% w / v$ penicillin-streptomycin and were maintained in an incubator at $37^{\circ} \mathrm{C}$ and $5 \% \mathrm{CO}_{2}$. 3T3-L1 cells were differentiated into adipocytes. For that purpose, $1 \times 10^{6}$ cells were seeded in 6 -well plates, and 2 days after reaching confluence (day 0), they were incubated for $48 \mathrm{~h}$ in DMEM supplemented with $10 \% \mathrm{FBS}, 1 \mu \mathrm{g} / \mathrm{mL}$ of insulin, $1 \mathrm{mM}$ dexamethasone, and $0.5 \mathrm{mM}$ IBMX. Cells were then incubated with DMEM containing $1 \mu \mathrm{g} / \mathrm{mL}$ of insulin for another $48 \mathrm{~h}$. From days 4 to 8 , cells were maintained with DMEM supplemented with $10 \%$ FBS. At day 8 , cells were considered mature adipocytes. Differentiation process was confirmed by Oil Red staining as previously described [51].

In order to simulate obesity conditions, bEnd. 3 cells, transfected or not, were treated with $30 \mathrm{mM}$ glucose and $300 \mu \mathrm{M}$ palmitic acid [52] for $24 \mathrm{~h}$ (Glu + PA conditioned media). After this time, the conditioned media was collected and added to mature adipocytes for $24 \mathrm{~h}$.

\subsection{Transient Transfection}

The endothelial bEnd.3 cell line was transfected with the pcDNA3.2-NOX5-B expression plasmid [53] employing the Lipofectamine 3000 Transfection Kit according to manufacturer's instructions. Briefly, $3 \times 10^{5}$ cells per well were seeded in 6-well plates in a total volume of $2 \mathrm{~mL}$. Then, $2.5 \mu \mathrm{g}$ of plasmid were mixed with $5 \mu \mathrm{g}$ of Lipofectamine 3000 in $250 \mu \mathrm{L}$ of Opti-MEM. Transfection mix was added to the cells in the presence of DMEM without FBS and antibiotics for $5 \mathrm{~h}$. Following this, complete medium was added, and incubation continued for $24 \mathrm{~h}$. After this time, cells were treated for each assay. Control cells were transfected with an empty pcDNA3.2 vector.

\subsection{Glucose Uptake Test}

Glucose Uptake-GloTM Assay (Promega, Madison, WI, USA) was used for glucose uptake measurement. At day 8 of differentiation, 3T3-L1 cells were treated with conditioned media from bEnd. 3 cells. After $24 \mathrm{~h}$, glucose uptake test was performed.

For that purpose, treated adipocytes were incubated with $100 \mathrm{nM}$ insulin for $10 \mathrm{~min}$. Cells were then washed with PBS to eliminate all remnant glucose, and $1 \mathrm{mM}$ 2-deoxyglucose (2DG) was added for $15 \mathrm{~min}$. STOP solution (lysis buffer) and neutralization buffer were added for $10 \mathrm{~min}$. Finally, labelled 2-deoxyglucose-6-phosphate (2DG6P) solution was added. Luminescence was read in a luminometer (Luminoskan Ascent, Thermo Fisher Scientific, Inc., Waltham, MA, USA) using an integration time of $0.3 \mathrm{~s}$.

\subsection{Quantitative Real-Time PCR}

RNA from animal tissue samples (liver, mesenteric and epididymal fat) and 3T3L1 adipocytes was extracted using Trizol (Thermo Fisher Scientific, Inc., Waltham, MA, USA) following standard protocols. cDNA was obtained from $2 \mu \mathrm{g}$ of RNA using MMLV Reverse Transcription enzyme (Thermo Fisher Scientific, Inc., Waltham, MA, USA). Gene expression was analysed using Taqman universal PCR Master Mix (Applied Biosystems, Cheshire, UK) and following a standard protocol: $50^{\circ} \mathrm{C}$ for $2 \mathrm{~min}, 95^{\circ} \mathrm{C}$ for $10 \mathrm{~min}$, 40 cycles of denaturing at $95{ }^{\circ} \mathrm{C}$ during $15 \mathrm{~s}$ plus an annealing/extension step at $60^{\circ} \mathrm{C}$ for $1 \mathrm{~min}$. Specific Taqman probes (Applied Biosystems, Cheshire, UK) were used for each gene: insulin receptor $\beta$ (Ir-B, Mm_01211875_m1), caveolin 1 (Cav1, Mm_00483057_m1), Slc2a4 (Glut4, Mm_00436615_m1), and glyceraldehyde 3-phosphate dehydrogenase(Gapdh, 
Mm_05724508_g1). All reactions were performed in triplicate. Gapdh was used as invariant internal control for qPCR and subsequent normalization. Relative quantification followed $2^{-\Delta \Delta \mathrm{Ct}}$ method [54].

\subsection{Western Blot}

Proteins from tissue samples (liver, mesenteric and epididymal fat) and 3T3-L1 adipocytes were obtained using RIPA buffer $(25 \mathrm{mM}$ Tris-HCl, $150 \mathrm{mM} \mathrm{NaCl}, 0.1 \% w / v$ SDS, $1 \% w / v$ sodium deoxycholate, $1 \% v / v$ IGEPAL) supplemented with a protease inhibitor cocktail (Roche, Basel, Switzerland). A total of $30 \mu \mathrm{g}$ of proteins were dissolved in loading buffer, and electrophoresis was performed at $120 \mathrm{~V}$ for $90 \mathrm{~min}$ in 10\% SDS-PAGE. Proteins were then transferred onto a nitrocellulose membrane (GE Healthcare Amersham, Chicago, IL, USA) for $60 \mathrm{~min}$ at $0.35 \mathrm{~A}$. Membranes were blocked with $5 \% w / v$ milk mixed with TBS (0.2 M Tris- $\mathrm{HCl}$ and $1.5 \mathrm{M} \mathrm{NaCl}$ at $\mathrm{pH} 7.4,0.1 \% w / v$ Tween) for $60 \mathrm{~min}$. Membranes were incubated overnight at $4{ }^{\circ} \mathrm{C}$ with specific primary antibodies at the appropriate dilutions: CAV1 (1:5000; Sc-894, Santa Cruz Biotechnology, Dallas, TX, USA), IR-B (1:1000; Sc-711, Santa Cruz Biotechnology), GLUT4 (1:1000; G4048, Sigma-Aldrich), Nitrotyrosine (1:500; AB5411, Merck; AB5411, Sigma-Aldrich), and B-ACTIN (1:10,000; A1978, Sigma-Aldrich). After $1 \mathrm{~h}$ incubation with secondary antibody at the appropriate dilutions, anti-rabbit (1:5000; NA934V, GE Healthcare) and anti-mouse (1:10,000; NA931V, GE Healthcare) membranes were developed by using Lumi-LightPlus Western Blotting Substrate (GE Healthcare Amersham, Chicago, IL, USA). Images were captured using a ChemiDOC XRS (Bio-Rad, Hercules, CA, USA) and analysed by Quantity One 1D software (Bio-Rad, Hercules, California, USA). B-ACTIN was used as invariant internal control for subsequent normalization.

\subsection{Statistical Analysis}

For groups following a normal distribution, results were expressed as mean \pm standard error of the mean (SEM). For groups following a non-normal distribution, results were expressed as median with confidence interval. Normality and homogeneity of variance for each group were checked by Shapiro-Wilk and Flinger test, respectively. For in vivo data, comparisons among groups were performed employing two-way ANOVA (parametric) or Aligned Rank transformation ANOVA (non-parametric) test. For glucose curve t-test was used. For in vitro data, comparisons among groups were performed employing ANOVA (parametric) or Kruskal-Wallis (non-parametric) tests. Post-estimations were calculated using Holm correction. The statistical analysis was performed using RStudio (RStudio Team, 2020) and graphs were generated using GraphPad Prism 8 (GraphPad, San Diego, CA, USA).

Supplementary Materials: The following are available online at https:/ /www.mdpi.com/1422-006 7/22/5/2729/s1: Figure S1: Endothelial NOX5 expression increased albumin nitrotyrosine levels in mesenteric fat of mice fed a HFD for 10 weeks. Figure S2: Endothelial NOX5 expression tended to increase Cav1 levels in liver in mice fed with HFD for 10 weeks. Figure S3: NOX5 transfection of bEnd. 3 cell line. Table S1: Biochemical parameters determined from plasma samples of mice.

Author Contributions: Conceptualization: J.G.G., E.A., F.I.M. and C.d.M.; methodology: J.G.G.; software: J.G.G.; formal analysis: J.G.G.; investigation: J.G.G., E.A. and C.d.M.; writing—original draft preparation: J.G.G., E.A. and C.d.M.; writing—review and editing: E.A., F.I.M., G.Z. and C.d.M.; supervision: E.A., F.I.M., G.Z. and C.d.M. All authors have read and agreed to the published version of the manuscript.

Funding: This project was funded by grants from the Ministry of Economy and Competitiveness, Madrid, Spain (SAF2013-49088-R, SAF2016-79151-R).

Institutional Review Board Statement: Experiments were performed in accordance with the European Communities Council Directives guidelines for the care and use of laboratory animals (2016/63/EU) and were approved by the University of Navarra Animal Research Review Committee (Protocol 106-17). 
Informed Consent Statement: Not applicable.

Data Availability Statement: The data presented in this study are available on request from the corresponding author.

Acknowledgments: We thank Álvaro Pejenaute and Juan Du for their contributions with the in vivo model; the technicians from our group, Maite Sesma and Maria Martínez; and Asociación de Amigos of the University of Navarra and La Caixa Foundation for their predoctoral grants.

Conflicts of Interest: The authors declare no conflict of interest.

\section{References}

1. Heyn, G.S.; Correa, L.H.; Magalhaes, K.G. The impact of adipose tissue-derived miRNAs in metabolic syndrome, obesity, and cancer. Front. Endocrinol. 2020, 11, 563816. [CrossRef]

2. Jung, U.J.; Choi, M.S. Obesity and its metabolic complications: The role of adipokines and the relationship between obesity, inflammation, insulin resistance, dyslipidemia and nonalcoholic fatty liver disease. Int. J. Mol. Sci. 2014, 15, 6184-6223. [CrossRef] [PubMed]

3. Boucher, J.; Kleinridders, A.; Kahn, C.R. Insulin receptor signaling in normal and insulin-resistant states. Cold Spring Harb. Perspect. Biol. 2014, 6. [CrossRef] [PubMed]

4. Nystrom, F.H.; Chen, H.; Cong, L.N.; Li, Y.; Quon, M.J. Caveolin-1 interacts with the insulin receptor and can differentially modulate insulin signaling in transfected Cos-7 cells and rat adipose cells. Mol. Endocrinol. 1999, 13, 2013-2024. [CrossRef]

5. Sowa, G. Caveolae, caveolins, cavins, and endothelial cell function: New insights. Front. Physiol. 2012, 2, 120. [CrossRef]

6. Gonzalez-Munoz, E.; Lopez-Iglesias, C.; Calvo, M.; Palacin, M.; Zorzano, A.; Camps, M. Caveolin-1 loss of function accelerates glucose transporter 4 and insulin receptor degradation in 3T3-L1 adipocytes. Endocrinology 2009, 150, 3493-3502. [CrossRef] [PubMed]

7. Fernandez-Real, J.M.; Catalan, V.; Moreno-Navarrete, J.M.; Gomez-Ambrosi, J.; Ortega, F.J.; Rodriguez-Hermosa, J.I.; Ricart, W.; Fruhbeck, G. Study of caveolin-1 gene expression in whole adipose tissue and its subfractions and during differentiation of human adipocytes. Nutr. Metab. 2010, 7, 20. [CrossRef]

8. Xue, W.; Wang, J.; Jiang, W.; Shi, C.; Wang, X.; Huang, Y.; Hu, C. Caveolin-1 alleviates lipid accumulation in NAFLD associated with promoting autophagy by inhibiting the Akt/mTOR pathway. Eur. J. Pharm. 2020, 871, 172910. [CrossRef] [PubMed]

9. Furukawa, S.; Fujita, T.; Shimabukuro, M.; Iwaki, M.; Yamada, Y.; Nakajima, Y.; Nakayama, O.; Makishima, M.; Matsuda, M.; Shimomura, I. Increased oxidative stress in obesity and its impact on metabolic syndrome. J. Clin. Investig. 2004, 114, 1752-1761. [CrossRef]

10. Sakai, K.; Matsumoto, K.; Nishikawa, T.; Suefuji, M.; Nakamaru, K.; Hirashima, Y.; Kawashima, J.; Shirotani, T.; Ichinose, K.; Brownlee, M.; et al. Mitochondrial reactive oxygen species reduce insulin secretion by pancreatic beta-cells. Biochem. Biophys. Res. Commun. 2003, 300, 216-222. [CrossRef]

11. Droge, W. Free radicals in the physiological control of cell function. Physiol. Rev. 2002, 82, 47-95. [CrossRef] [PubMed]

12. Bedard, K.; Krause, K.H. The NOX family of ROS-generating NADPH oxidases: Physiology and pathophysiology. Physiol. Rev. 2007, 87, 245-313. [CrossRef] [PubMed]

13. Frey, R.S.; Ushio-Fukai, M.; Malik, A.B. NADPH oxidase-dependent signaling in endothelial cells: Role in physiology and pathophysiology. Antioxid. Redox Signal. 2009, 11, 791-810. [CrossRef] [PubMed]

14. Banfi, B.; Molnar, G.; Maturana, A.; Steger, K.; Hegedus, B.; Demaurex, N.; Krause, K.H.A. Ca(2+)-activated NADPH oxidase in testis, spleen, and lymph nodes. J. Biol. Chem. 2001, 276, 37594-37601. [CrossRef]

15. Cheng, G.; Cao, Z.; Xu, X.; van Meir, E.G.; Lambeth, J.D. Homologs of gp91phox: Cloning and tissue expression of Nox3, Nox4, and Nox5. Gene 2001, 269, 131-140. [CrossRef]

16. Fulton, D.J. Nox5 and the regulation of cellular function. Antioxid. Redox Signal. 2009, 11, 2443-2452. [CrossRef]

17. Garcia-Redondo, A.B.; Aguado, A.; Briones, A.M.; Salaices, M. NADPH oxidases and vascular remodeling in cardiovascular diseases. Pharm. Res. 2016, 114, 110-120. [CrossRef]

18. DeVallance, E.; Li, Y.; Jurczak, M.J.; Cifuentes-Pagano, E.; Pagano, P.J. The role of NADPH oxidases in the etiology of obesity and metabolic syndrome: Contribution of individual isoforms and cell biology. Antioxid. Redox Signal. 2019, 31, 687-709. [CrossRef] [PubMed]

19. Han, C.Y.; Umemoto, T.; Omer, M.; Den Hartigh, L.J.; Chiba, T.; LeBoeuf, R.; Buller, C.L.; Sweet, I.R.; Pennathur, S.; Abel, E.D.; et al. NADPH oxidase-derived reactive oxygen species increases expression of monocyte chemotactic factor genes in cultured adipocytes. J. Biol. Chem. 2012, 287, 10379-10393. [CrossRef]

20. Houstis, N.; Rosen, E.D.; Lander, E.S. Reactive oxygen species have a causal role in multiple forms of insulin resistance. Nature 2006, 440, 944-948. [CrossRef]

21. Schroder, K.; Wandzioch, K.; Helmcke, I.; Brandes, R.P. Nox4 acts as a switch between differentiation and proliferation in preadipocytes. Arter. Thromb. Vasc. Biol. 2009, 29, 239-245. [CrossRef] 
22. Mahadev, K.; Motoshima, H.; Wu, X.; Ruddy, J.M.; Arnold, R.S.; Cheng, G.; Lambeth, J.D.; Goldstein, B.J. The NAD(P)H oxidase homolog Nox4 modulates insulin-stimulated generation of $\mathrm{H} 2 \mathrm{O} 2$ and plays an integral role in insulin signal transduction. Mol. Cell. Biol. 2004, 24, 1844-1854. [CrossRef]

23. Anagnostopoulou, A.; Camargo, L.L.; Rodrigues, D.; Montezano, A.C.; Touyz, R.M. Importance of cholesterol-rich microdomains in the regulation of Nox isoforms and redox signaling in human vascular smooth muscle cells. Sci. Rep. 2020, 10, 17818. [CrossRef] [PubMed]

24. Chen, F.; Barman, S.; Yu, Y.; Haigh, S.; Wang, Y.; Black, S.M.; Rafikov, R.; Dou, H.; Bagi, Z.; Han, W.; et al. Caveolin-1 is a negative regulator of NADPH oxidase-derived reactive oxygen species. Free Radic. Biol. Med. 2014, 73, 201-213. [CrossRef] [PubMed]

25. Hasan, S.S.; Fischer, A. The endothelium: An active regulator of lipid and glucose homeostasis. Trends Cell. Biol. 2021, 31, 37-49. [CrossRef] [PubMed]

26. Marques, J.; Cortes, A.; Pejenaute, A.; Ansorena, E.; Abizanda, G.; Prosper, F.; Martinez-Irujo, J.J.; Miguel, C.; Zalba, G. Induction of cyclooxygenase-2 by overexpression of the human NADPH oxidase 5 (NOX5) gene in aortic endothelial cells. Cells 2020, 9, 637. [CrossRef] [PubMed]

27. Youn, J.Y.; Siu, K.L.; Lob, H.E.; Itani, H.; Harrison, D.G.; Cai, H. Role of vascular oxidative stress in obesity and metabolic syndrome. Diabetes 2014, 63, 2344-2355. [CrossRef]

28. Sukumar, P.; Viswambharan, H.; Imrie, H.; Cubbon, R.M.; Yuldasheva, N.; Gage, M.; Galloway, S.; Skromna, A.; Kandavelu, P.; Santos, C.X.; et al. Nox2 NADPH oxidase has a critical role in insulin resistance-related endothelial cell dysfunction. Diabetes 2013, 62, 2130-2134. [CrossRef]

29. Den Hartigh, L.J.; Omer, M.; Goodspeed, L.; Wang, S.; Wietecha, T.; O’Brien, K.D.; Han, C.Y. Adipocyte-specific deficiency of NADPH oxidase 4 delays the onset of insulin resistance and attenuates adipose tissue inflammation in obesity. Arterioscler. Thromb. Vasc. Biol. 2017, 37, 466-475. [CrossRef] [PubMed]

30. Bouzakri, K.; Veyrat-Durebex, C.; Holterman, C.; Arous, C.; Barbieux, C.; Bosco, D.; Altirriba, J.; Alibashe, M.; Tournier, B.B.; Gunton, J.E.; et al. Beta-cell-specific expression of nicotinamide adenine dinucleotide phosphate oxidase 5 aggravates high-fat diet-induced impairment of islet insulin secretion in mice. Antioxid. Redox Signal. 2020, 32, 618-635. [CrossRef]

31. Hahn, N.E.; Meischl, C.; Kawahara, T.; Musters, R.J.; Verhoef, V.M.; van der Velden, J.; Vonk, A.B.; Paulus, W.J.; van Rossum, A.C.; Niessen, H.W.; et al. NOX5 expression is increased in intramyocardial blood vessels and cardiomyocytes after acute myocardial infarction in humans. Am. J. Pathol. 2012, 180, 2222-2229. [CrossRef] [PubMed]

32. Jha, J.C.; Banal, C.; Okabe, J.; Gray, S.P.; Hettige, T.; Chow, B.S.M.; Thallas-Bonke, V.; De Vos, L.; Holterman, C.E.; Coughlan, M.T.; et al. NADPH oxidase Nox5 accelerates renal injury in diabetic nephropathy. Diabetes 2017, 66, 2691-2703. [CrossRef] [PubMed]

33. Marzaioli, V.; Hurtado-Nedelec, M.; Pintard, C.; Tlili, A.; Marie, J.C.; Monteiro, R.C.; Gougerot-Pocidalo, M.A.; Dang, P.M.; El-Benna, J. NOX5 and p22phox are 2 novel regulators of human monocytic differentiation into dendritic cells. Blood 2017, 130, 1734-1745. [CrossRef] [PubMed]

34. Violi, F.; Carnevale, R.; Loffredo, L.; Pignatelli, P.; Gallin, J.I. NADPH oxidase-2 and atherothrombosis: Insight from chronic granulomatous disease. Arter. Thromb. Vasc. Biol. 2017, 37, 218-225. [CrossRef] [PubMed]

35. Li, Y.; Mouche, S.; Sajic, T.; Veyrat-Durebex, C.; Supale, R.; Pierroz, D.; Ferrari, S.; Negro, F.; Hasler, U.; Feraille, E.; et al. Deficiency in the NADPH oxidase 4 predisposes towards diet-induced obesity. Int. J. Obes. 2012, 36, 1503-1513. [CrossRef] [PubMed]

36. Benani, A.; Troy, S.; Carmona, M.C.; Fioramonti, X.; Lorsignol, A.; Leloup, C.; Casteilla, L.; Penicaud, L. Role for mitochondrial reactive oxygen species in brain lipid sensing: Redox regulation of food intake. Diabetes 2007, 56, 152-160. [CrossRef]

37. Shadel, G.S.; Horvath, T.L. Mitochondrial ROS signaling in organismal homeostasis. Cell 2015, 163, 560-569. [CrossRef]

38. Wang, Y.; Dellatore, P.; Douard, V.; Qin, L.; Watford, M.; Ferraris, R.P.; Lin, T.; Shapses, S.A. High fat diet enriched with saturated, but not monounsaturated fatty acids adversely affects femur, and both diets increase calcium absorption in older female mice. Nutr. Res. 2016, 36, 742-750. [CrossRef] [PubMed]

39. Kahn, S.E.; Hull, R.L.; Utzschneider, K.M. Mechanisms linking obesity to insulin resistance and type 2 diabetes. Nature 2006, 444, 840-846. [CrossRef]

40. Leloup, C.; Tourrel-Cuzin, C.; Magnan, C.; Karaca, M.; Castel, J.; Carneiro, L.; Colombani, A.L.; Ktorza, A.; Casteilla, L.; Penicaud, L. Mitochondrial reactive oxygen species are obligatory signals for glucose-induced insulin secretion. Diabetes 2009, 58, 673-681. [CrossRef] [PubMed]

41. Loh, K.; Deng, H.; Fukushima, A.; Cai, X.; Boivin, B.; Galic, S.; Bruce, C.; Shields, B.J.; Skiba, B.; Ooms, L.M.; et al. Reactive oxygen species enhance insulin sensitivity. Cell Metab. 2009, 10, 260-272. [CrossRef]

42. Barquissau, V.; Capel, F.; Dardevet, D.; Feillet-Coudray, C.; Gallinier, A.; Chauvin, M.A.; Rieusset, J.; Morio, B. Reactive oxygen species enhance mitochondrial function, insulin sensitivity and glucose uptake in skeletal muscle of senescence accelerated prone mice SAMP8. Free Radic. Biol. Med. 2017, 113, 267-279. [CrossRef]

43. Gomez-Ruiz, A.; Milagro, F.I.; Campion, J.; Martinez, J.A.; de Miguel, C. Caveolin expression and activation in retroperitoneal and subcutaneous adipocytes: Influence of a high-fat diet. J. Cell. Physiol. 2010, 225, 206-213. [CrossRef]

44. Vargas, E.; Podder, V.; Sepulveda, M.A.C. Physiology, Glucose Transporter Type 4; Stat Pearls Publishing: Treasure Island, FL, USA, 2020. Available online: https:/ / www.ncbi.nlm.nih.gov/books/NBK537322 (accessed on 5 March 2021).

45. Shvets, E.; Ludwig, A.; Nichols, B.J. News from the caves: Update on the structure and function of caveolae. Curr. Opin. Cell Biol. 2014, 29, 99-106. [CrossRef] [PubMed] 
46. Haddad, D.; Al Madhoun, A.; Nizam, R.; Al-Mulla, F. Role of caveolin-1 in diabetes and its complications. Oxid. Med. Cell. Longev. 2020, 2020, 9761539. [CrossRef] [PubMed]

47. Cohen, A.W.; Razani, B.; Wang, X.B.; Combs, T.P.; Williams, T.M.; Scherer, P.E.; Lisanti, M.P. Caveolin-1-deficient mice show insulin resistance and defective insulin receptor protein expression in adipose tissue. Am. J. Physiol. Cell Physiol. 2003, 285, C222-C235. [CrossRef]

48. Cohen, A.W.; Hnasko, R.; Schubert, W.; Lisanti, M.P. Role of caveolae and caveolins in health and disease. Physiol. Rev. 2004, 84, 1341-1379. [CrossRef] [PubMed]

49. Cao, H.; Alston, L.; Ruschman, J.; Hegele, R.A. Heterozygous CAV1 frameshift mutations (MIM 601047) in patients with atypical partial lipodystrophy and hypertriglyceridemia. Lipids Health Dis. 2008, 7, 3. [CrossRef]

50. Dasari, A.; Bartholomew, J.N.; Volonte, D.; Galbiati, F. Oxidative stress induces premature senescence by stimulating caveolin1 gene transcription through p38 mitogen-activated protein kinase/Sp1-mediated activation of two GC-rich promoter elements. Cancer Res. 2006, 66, 10805-10814. [CrossRef]

51. Varela-Guruceaga, M.; Milagro, F.I.; Martinez, J.A.; de Miguel, C. Effect of hypoxia on caveolae-related protein expression and insulin signaling in adipocytes. Mol. Cell. Endocrinol. 2018, 473, 257-267. [CrossRef]

52. Patkova, J.; Andel, M.; Trnka, J. Palmitate-induced cell death and mitochondrial respiratory dysfunction in myoblasts are not prevented by mitochondria-targeted antioxidants. Cell. Physiol. Biochem. 2014, 33, 1439-1451. [CrossRef] [PubMed]

53. Andueza, A.; Garde, N.; Garcia-Garzon, A.; Ansorena, E.; Lopez-Zabalza, M.J.; Iraburu, M.J.; Zalba, G.; Martinez-Irujo, J.J NADPH oxidase 5 promotes proliferation and fibrosis in human hepatic stellate cells. Free Radic. Biol. Med. 2018, 126, 15-26. [CrossRef]

54. Livak, K.J.; Schmittgen, T.D. Analysis of relative gene expression data using real-time quantitative PCR and the 2(-Delta Delta C(T)) Method. Methods 2001, 25, 402-408. [CrossRef] [PubMed] 